\title{
Tracing the acclimation of European beech (Fagus sylvatica L.) populations to climatic stress by analyzing the antioxidant system
}

\author{
Eszter Visi-Rajczi ${ }^{(1)}$, \\ Tamás Hofmann ${ }^{(1)}$, \\ Levente Albert ${ }^{(1)}$, \\ Csaba Mátyás ${ }^{(2)}$
}

\begin{abstract}
Through a common garden (provenance) experiment, we investigated the metabolic responses to climatic stress with regard to the acclimation potential of different European beech (Fagus sylvatica L.) populations. Selected enzymatic and non-enzymatic antioxidants were analyzed in leaves. Peroxidase (POD) and polyphenol oxidase (PPO) enzyme activity, total protein content as well as ABTS [2,2'-azino-bis-(3-etylbenzothiazoline)-6-sulphonic acid] antioxidant capacity were measured in the leaves of selected populations. Major leaf polyphenols were identified and their relative amounts were compared. Significant correlations were found between phenotypic (diameter growth) response to simulated climatic stress and the activity (and amount) of selected chemical components. The concentrations of certain polyphenols, POD enzyme activity, and total protein content may be chemical indicators of the acclimation potential of populations and may contribute to the forecasting of climate change ef fects, which can aid in the selection of suitable propagation material for adaptive silviculture.
\end{abstract}

Keywords: Beech, Drought Stress, Antioxidants, Phenotypic Plasticity, Provenance Trial, Climate Change

even local extinction in areas exposed to hotter and more extreme droughts, especially at the xeric, low-elevation distribution limits (Mátyás et al. 2010, Stojanovic et al. 2013). Compared to conifers (Sáenz-Ro mero et al. 2019), beech has demonstrated higher adaptability and acclimation potential. In a European network of common gardens, beech has displayed modest between-population phenotypic differentiation, indicating a good adaptability of the species (Von Wuehlisch \& Alia 2011).

To maintain functional flexibility under fluctuating conditions, sessile organisms with extremely long life cycles, such as forest trees, are highly dependent on mechanisms to sustain physiological and developmental processes. During acclimation to stress, photosynthesis products are allocated to secondary metabolites that influence growth. Types and concentrations of metabolites may vary by species and by genotypes within species (Isah 2019). Although such research has already been conducted for some plant species (Grace \& Logan 1996, Pennycooke et al. 2005), results for forest trees are limited to cuttings (Popovic et al. 2016, Zhang et al. 2012) or involve mature trees growing in forest ecosystems (Luwe 1996, Haberer et al. 2008, Zolfaghari et al. 2010).

Within-species genetic differences may influence the vulnerability of beech populations, especially at the continental (Berki et al. 2009, Lakatos \& Molnár 2009, Czúcz et al. 2011) and Mediterranean habitats (Penuelas et al. 2007). Research on the role of metabolic processes and their links to inherited resilience in acclimation may sup- port the development of adaptive measures in forestry in view of projected changes.

Through biochemical analysis focused on the antioxidant system - a major defense pathway of plants - the present work assessed stress amounts and the effects these had on European beech. Most stress factors trigger oxidative stress, which is interpreted as a shift in the balance of oxidants and antioxidants toward the dominance of the oxidants (Sies 1991). Oxidative stress is mostly realized by reactive oxygen species (ROS) that are normally present in the biochemical processes of living organisms. ROS levels rise during periods of oxidative stress, which subsequently affects various parts of living cells (Foyer \& Noctor 2005) by triggering reaction chains that cause irreversible damage to living organisms. Plants activate their complex antioxidant pathways to block cell and tissue damage, which has been the subject of numerous studies and reviews (Del Río 2015, Gupta et al. 2018).

Regarding molecular structure, antioxidants can be enzymatic and non-enzymatic. Polyphenols are important types of non-enzymatic antioxidants that participate in defense reactions against biotic and abiotic stress in plants (Dalmagro et al. 2018, Achmadi 2019). Furthermore, polyphenols are also responsible for color effects (plant pigments), biochemical signaling in ripening, growth processes, and hormone regulating effects (Tanase et al. 2019). The most recent and detailed investigation on beech leaf polyphenols was conducted by Cadahía et al. (2015), Aranda et 
al. (2017) and Hofmann et al. (2017a). These studies used the HPLC-MS/MS technique to identify the main polyphenolic compounds in beech leaves.

The most important enzymes involved in oxidative stress defense are catalase, superoxide dismutase, and the enzymes responsible for glutathione transformation (oxidase, peroxidase, and reductase). The investigation of the enzymatic antioxidant system in the stress response of beech has proven that peroxidase (POD) and poly phenol oxidase (PPO) enzymes participate in defense reactions and can, thereby, be possible indicators of acclimation triggered by climatic stress (Haberer et al. 2008, Zolfaghari et al. 2010, Visiné Rajczi et al. 2018). Earlier allozyme study results support the climatic sensitivity of peroxidases. Significant geographic trends in both the latitudinal (Comps et al. 1998) and altitudinal (Comps et al. 1990) distribution of peroxidase isomers have been observed, which may - parallel to random impacts - also indicate the effect of climatic gradients on allozyme frequency across the European range of beech. As both enzymatic and non-enzymatic antioxidants are essential to the proper life functions of living organisms, we have supposed that the concentration of certain polyphenols and antioxidant enzyme activity could be chemical in dicators of the acclimation (phenotypic plasticity) potential of populations. These indicators could forecast future responses to climate change within the populations.

The present work investigated the level changes of selected compounds in the leaf antioxidant systems of different beech provenances as they reacted to translocation stress. Acclimation stress intensity was approximated by the environmental change of populations being transferred from their places of origin to a common garden test, thereby providing a "spacefor-time" projection of expectable future responses. Our study is the first to investigate the effect of acclimation stress on antioxidant types and concentrations in different European beech provenances. The research aimed to prove that the differentiated responses to stress exposure of beech provenances can be tracked by monitoring selected antioxidants. Some of these compounds may characterize the acclimation processes at the molecular level, and their changes may provide insights into drought-triggered processes in forest trees, thus helping to develop strategies for future afforestation.

\section{Materials and methods}

\section{Basic experimental data and the investigated provenances}

The European Cooperation in Science and Technology "Evaluation of Beech Genetic Resources for Sustainable Forestry" COST BeechE52 - a European research consortium - established a network of close to 20 beech provenance tests across Europe in 1998 (Von Wuehlisch \& Alia 2011). The test contains 36 different provenances, predominantly from Western and Central Europe (Fig. 1). In these regions, nearly all the provenances in the network experience warmer and drier climates than they would at their origin sites (Horváth \& Mátyás 2014). Seedlings were centrally raised in a nursery garden near Hamburg (Germany). After two years, the seedlings were transferred to the European trial sites. The Hungarian experimental site within the network was established in the south-western part of the country near Bucsuta (Zala County). Experimental plots were arranged randomly, with three repetitions (Horváth \& Mátyás 2014, 2016). The Hungarian location is particularly interesting for studying acclimation because it is situated at the low-elevation edge of the climate-zonal distribution of European beech, i.e., at the xeric limit.

Six provenances with largely varying original climatic backgrounds were selected for the current study. The populations from Farchau (Germany), Torup (Sweden), and Gråsten (Denmark) have adapted to a cooler and wetter Atlantic climate. Pidkamin originates from the eastern-continental limit of the species in the Ukraine. Magyaregregy and Bánokszentgyörgy, represent the two Hungarian provenances, with the latter containing trees of local origin. Tab. 1 lists the main climatic data of provenances. The mean diameter of the selected representative trees within the populations, which were used for correlating biochemical parameters with phenotype, were measured during the annual leaf sampling of trees that were 16-19 years old (see Tab. S1 in Supplementary material).

\section{Climate data}

Fifty years of temperature and precipitation data (1951-2000) for the original provenance locations were extracted from the WorldClim database (Hijmans et al. 2005). Weather data from the nearest $(18 \mathrm{~km})$ meteorological station in Nagykanizsa were used for the Bucsuta test site (Horváth \& Mátyás 2014). Employed here as a drought index, Ellenberg's climate quotient (EQ Ellenberg 1988) was calculated from the temperature quotient of the hottest month (July in Central Europe, $T_{07}$ ) and annual precipitation $\left(P_{a n n}-\right.$ eqn. 1$)$ :

$$
E Q=1000 \cdot T_{07} \cdot P_{a n n}^{-1}
$$

To characterize the climate at the original locations to which the populations were adapted, the EQ quotients were calculated from the 50-year mean July temperatures $\left(\mathrm{T}_{07},{ }^{\circ} \mathrm{C}\right)$ and the 50-year mean annual precipitations $\left(P_{a n n}, \mathrm{~mm}\right)$. Fifteen-year averages (1998-2013), from planting to measurement, were used for the EQ value cal-

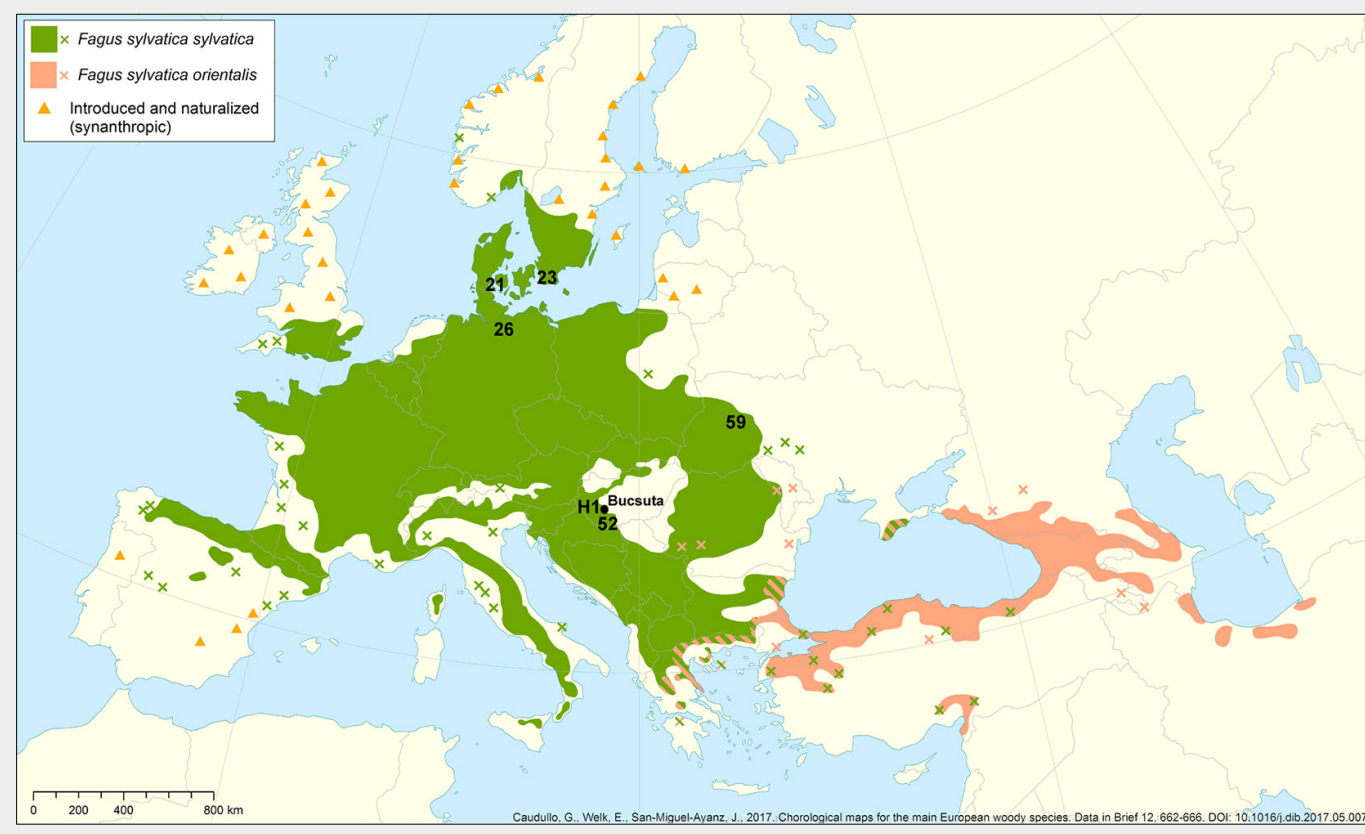

Fig. 1 - The provenances represented in the beech provenance test in Bucsuta (Hungary) with the investigated populations: 21: Gråsten (DK); 23: Torup (S); 52: Magyaregregy $(\mathrm{H})$; $\mathrm{H} 1$ : Bánokszentgyörgy $(H)$; 59: Pidkamin (UA); 26: Farchau (D). Adapted from Caudullo et al. (2017). 
culation of the Bucsuta test site, representing the reference period to which the trees were responding.

Ecodistance $(\Delta \mathrm{EQ})$ was calculated as the climate difference between the test location and the original location (Mátyás 1994). For the assessment of climatic change due to population transfer, we used the difference between the earliest available past climate data for the origin of a provenance and the data for the 15-year test period in Bucsuta (Horváth \& Mátyás 2016). Depending on the EQ value of the original location, negative ecodistance values represent cooler/wetter conditions, while positive differences reflect warmer/ drier conditions for the transferred populations at the test site.

Sample collection for chemical analysis

For the polyphenol and ABTS antioxidant capacity investigations, a sample collection was conducted at the end of June 2014. The sample collection was as follows: eight trees were assigned from each of the investigated six provenances and altogether 40 leaves were sampled randomly from two different positions (sunned leaves and shaded leaves) of each tree canopy. Leaf samples were put in dry ice immediately after collection and stored there until extraction.

Sample collection for the investigation of the enzymatic antioxidant system was completed at the end of June, in three subsequent years (2015-2017). Four trees were selected from the previously assigned eight trees in each of the six provenances. Leaf collection (20 randomly picked sunned leaves and 20 shaded leaves from each tree) and sample storage were executed as previously described.

\section{Enzyme activity analysis}

Frozen leaf samples were transferred to a grinder and ground into a fine powder in a frozen state. About $0.5 \mathrm{~g}$ leaf powder was homogenized vigorously with $10 \mathrm{ml}$ phosphate puffer ( $\mathrm{pH}: 5.6$, with $80 \mathrm{~g} \mathrm{~L}^{-1} \mathrm{PVP} 40$ ) for four minutes then centrifuged at 6000 $\mathrm{min}^{-1}$ for 10 minutes. The supernatant was collected and taken to analysis. Total protein content was assayed according to Bradford (1976). Bovine serum albumin (92\%) was used as a standard to quantify total protein content of the samples. The POD enzyme activity was determined using the method of Shannon et al. (1966) measuring absorbance change at $480 \mathrm{~nm}$ and regarding $0.01 \Delta \mathrm{A} \mathrm{min} \mathrm{m}^{-1}$ as 1 Unit. The PPO enzyme activity was assayed according to the method of Flurkey \& Jen (1978) at 420 $\mathrm{nm}$, taking $0.001 \Delta \mathrm{A} \mathrm{min}^{-1}$ as 1 Unit. All measurements were conducted in triplicates.

Investigation of non-enzymatic antioxidants

\section{Extraction}

Leaves were treated for two minutes by applying $750 \mathrm{~W}$ microwave energy to inac-

Tab. 1 - Main geographic and climatic data (including EQ) of sampled provenances at the original location for the period 1951-2000 and their ecodistance $(\Delta E Q)$, calculated for the test site Bucsuta (from Horváth \& Mátyás 2014). ( $\left.T_{07}\right)$ : July mean temperature; $\left(\mathrm{P}_{\mathrm{ann}}\right)$ : annual precipitation; ( $\left.\Delta \mathrm{EQ}\right)$ : eco-distance (see text).

\begin{tabular}{llccccc}
\hline $\begin{array}{l}\text { Provenance } \\
\text { (reg. number) }\end{array}$ & Country & $\begin{array}{c}\text { Elev. } \\
(\mathrm{m} \text { a.s.l.) }\end{array}$ & $\begin{array}{c}\mathrm{T}_{07} \\
\left({ }^{\circ} \mathrm{C}\right)\end{array}$ & $\begin{array}{c}\mathrm{P}_{\text {ann }} \\
(\mathrm{mm})\end{array}$ & $\begin{array}{c}\mathrm{EQ} \\
\text { index }\end{array}$ & $\Delta \mathrm{EQ}$ \\
\hline Farchau (26) & Germany & 55 & 17.3 & 676 & 25.6 & 3.86 \\
\hline Pidkamin (59) & Ukraine & - & 18.1 & 612 & 29.6 & -0.13 \\
\hline Torup (23) & Sweden & 40 & 16.6 & 634 & 26.2 & 3.27 \\
\hline Gråsten (21) & Denmark & 45 & 15.8 & 780 & 20.3 & 9.19 \\
\hline Magyaregregy (52) & Hungary & 400 & 19.0 & 707 & 26.9 & 2.57 \\
\hline Bánokszentgyörgy (H1) & Hungary & 200 & 20.0 & 747 & 26.8 & 2.67 \\
\hline Bucsuta test site & Hungary & 220 & 20.8 & 707 & 29.4 & - \\
\hline
\end{tabular}

tivate their polyphenol-oxidizing enzymes and avoid the oxidation of polyphenols during the extraction process (Hofmann et al. 2015). Leaves were ground and $0.15 \mathrm{~g}$ of the ground powder was extracted with 15 $\mathrm{ml}$ methanol:water $80: 20 \mathrm{v} / \mathrm{v}$ by stirring for $24 \mathrm{~h}$ in the dark. Extracts were filtered through a $0.45 \mu \mathrm{m}$ cellulose acetate membrane filter.

\section{ABTS assay of antioxidant capacity}

The ABTS assay was run as described by Stratil et al. (2007) at $734 \mathrm{~nm}$, using the $\mathrm{ABTS}^{\circ}$ radical ion and trolox standard. Reaction time was $10 \mathrm{~min}$. ABTS antioxidant capacity was evaluated as mg trolox $\mathrm{g}^{-1}$ dry leaf units. Measurements and evaluations were run in triplicates.

The HPLC-PDA-ESI-MS/MS separation and relative quantitative determination of leaf polyphenols

The separation and quantitative assessment of leaf polyphenols was completed using high-performance liquid chromatography separation and photodiode array as well as tandem electrospray mass spectrometry detection (HPLC-PDA-ESI-MS/ MS). In an earlier study, we identified 44 compounds, 38 of which were identified by name (Hofmann et al. 2017a).

For chromatographic separation, a Shimadzu LC $-20^{\oplus}$ type high-performance liquid chromatograph was used. This was coupled to a Shimadzu SPD-M20A ${ }^{\oplus}$ type diode array detector (PDA - Shimadzu Corporation, Kyoto, Japan) and an AB Sciex 3200 QTrap $^{\circledast}$ triple quadrupole/linear ion trap LC/ MS/MS detector ( $A B$ Sciex, Framingham, MA, USA). A Phenomenex Kinetex $\mathrm{C}_{18}{ }^{\oplus}$, $150 \times 4.6 \mathrm{~mm}, 2.6 \mu \mathrm{m}$ core-shell column was applied for the separation at $40^{\circ} \mathrm{C}$. The mobile phase $\left(1.2 \mathrm{~mL} \mathrm{~min}^{-1}\right)$ gradient of $A$ $\left(\mathrm{H}_{2} \mathrm{O}+0.1 \% \mathrm{HCOOH}\right)$ and $\mathrm{B}\left(\mathrm{CH}_{3} \mathrm{CN}+0.1 \%\right.$ $\mathrm{HCOOH})$ was run as follows: $10 \% \mathrm{~B}$ (0-1 $\mathrm{min}$ ), $12 \%$ B (8 min), 18\% B (10 min), 22\% B (13 min), $28 \%$ B (19 min), $98 \%$ B (23 min), $98 \%$ B (23-32 min), 10\% B (33 min), 10\% B (33-40 min). Prior to chromatographic separation, extracts were diluted two-fold with pure methanol:water $80: 20 \mathrm{v} / \mathrm{v}$ solution and $4 \mu \mathrm{l}$ of the diluted extracts were injected. The
PDA detection was executed in the wavelength range of $250-380 \mathrm{~nm}$. Flow-splitting was applied in front of the mass spectrometer using a split valve, which allowed 0.6

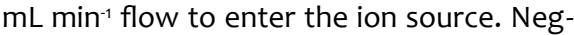
ative electrospray ionization mode with the following settings was employed: ion spray voltage: $-4500 \mathrm{~V}$; curtain gas $\left(\mathrm{N}_{2}\right)$ pressure: 30 psi; spray gas $\left(\mathrm{N}_{2}\right)$ pressure: 40 psi; drying gas $\left(\mathrm{N}_{2}\right)$ pressure: $30 \mathrm{psi}$; ion source temperature: $500^{\circ} \mathrm{C}$.

The MRM (multiple reaction monitoring) transitions, characteristic to the mass spectrometric fragmentation of each of the compounds as well as compound-optimized settings of the mass spectrometer, used for subsequent quantitative analysis, were determined by the direct infusion of the extracts into the mass spectrometer as described in Hofmann et al. (2017a). Quantitative assessment of the compounds was achieved using relative quantification, which involved the determination of peak areas by monitoring the respective MRM channel for each compound. Chromatographic data were acquired and processed using the software Analyst ${ }^{\oplus}$ v. 1.6.1.

\section{Chemicals}

Conventional distillation equipment was used to produce double distilled water for extraction and chromatography. Acetonitrile (LC-MS grade) was obtained from VWR-International (Budapest, Hungary). Potassium persulfate, 6-hydroxy-2,5,7,8tetramethylchroman-2-carboxylic acid (trolox), 2,2'-azino-bis(3-ethylbenzothiazoline-6sulphonic acid), sodium hydrogen phosphate, potassium dihydrogen phosphate, formic acid (98\%), bovine serum albumin (92\%), 3,3'-diaminobenzidine, polyvinylpyrrolidone (PVP-40), and Whatman GF/A glass fiber filter paper were procured from Sigma-Aldrich (Budapest, Hungary). Pyrocatechin, Coomassie Brilliant Blue G-250, ethanol, methanol, phosphoric acid, hydrogen peroxide were purchased from Reanal (Budapest, Hungary). Quercetin was obtained from Carl Roth $\mathrm{GmbH}$ (Karlsruhe, Germany). 
Tab. 2 - Correlation matrices using the data from 2015, 2016, and 2017 (see also Tab. S1 in Supplementary material). Significant correlations (for $p<0.15$ for $n=6 ;|R| \geq 0.664$ ) are marked with an asterisk.

\begin{tabular}{|c|c|c|c|c|c|c|}
\hline 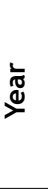 & Variables & 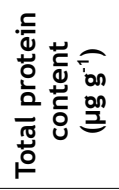 & 용 & 음 & 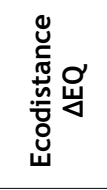 & 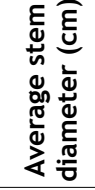 \\
\hline \multirow{5}{*}{$\stackrel{n}{\grave{N}}$} & Total protein content $\left(\mu \mathrm{g} \mathrm{g}^{-1}\right)$ & 1.000 & $-0.674^{*}$ & $-0.755^{*}$ & $0.854^{*}$ & -0.251 \\
\hline & POD $\left(U u^{-1}\right)$ & - & 1.000 & 0.161 & $-0.808^{*}$ & 0.575 \\
\hline & PPO $\left(\mathrm{U}\right.$ ug $\left.^{-1}\right)$ & - & - & 1.000 & -0.439 & -0.393 \\
\hline & $\Delta \mathrm{EQ}$ & - & - & - & 1.000 & -0.341 \\
\hline & Average stem diameter $(\mathrm{cm})$ & - & - & - & - & 1.000 \\
\hline \multirow{5}{*}{ 유 } & Total protein content $\left(\mu \mathrm{g} \mathrm{g}^{-1}\right)$ & 1.000 & -0.286 & -0.075 & $0.708^{*}$ & -0.032 \\
\hline & POD $\left(U u^{-1}\right)$ & - & 1.000 & 0.430 & -0.474 & $0.833^{*}$ \\
\hline & PPO $\left(U u^{-1}\right)$ & - & - & 1.000 & $-0.737^{*}$ & 0.583 \\
\hline & $\Delta \mathrm{EQ}$ & - & - & - & 1.000 & -0.339 \\
\hline & Average stem diameter $(\mathrm{cm})$ & - & - & - & - & 1.000 \\
\hline \multirow{5}{*}{ 호 } & Total protein content $\left(\mu \mathrm{g} \mathrm{g}^{-1}\right)$ & 1.000 & -0.024 & 0.016 & $0.679^{*}$ & 0.191 \\
\hline & POD (U ug $\left.{ }^{-1}\right)$ & - & 1.000 & -0.310 & -0.445 & $0.941^{*}$ \\
\hline & PPO $\left(\mathrm{U} \mathrm{ug}^{-1}\right)$ & - & - & 1.000 & -0.306 & -0.068 \\
\hline & $\Delta \mathrm{EQ}$ & - & - & - & 1.000 & -0.354 \\
\hline & Average stem diameter $(\mathrm{cm})$ & - & - & - & - & 1.000 \\
\hline
\end{tabular}

\section{Statistical evaluation}

Biochemical results were correlated with the climatic parameters (Ellenberg index: $E Q$, and ecodistance: $\Delta E Q$ ) as well as with provenance growth (average stem diameter). Correlation analysis was implemented by the evaluation of Pearson correlation coefficients. For the comparison of samples, ANOVA analysis was run by applying the Tukey HSD calculation method for post-hoc tests. In order to fulfil the requirements of the ANOVA analysis, measurement values were first checked for normal distribution, and then the variables were inspected for the homogeneity of vari-

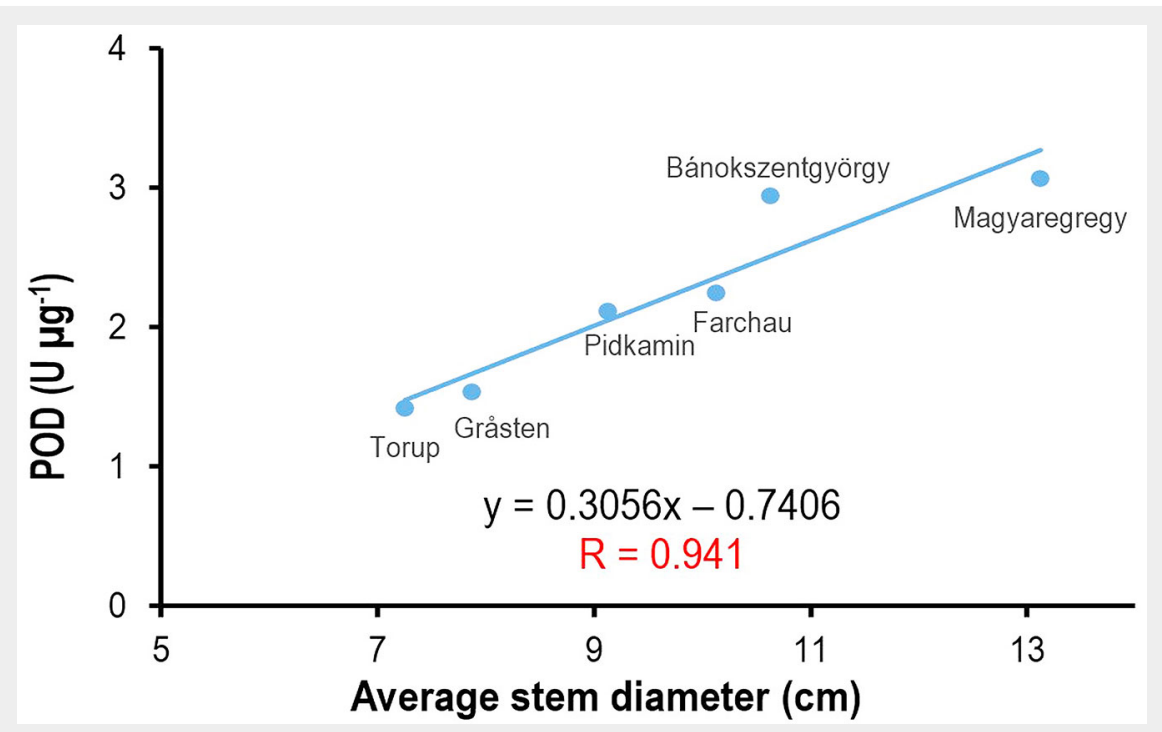

Fig. 2 - Correlation between average stem diameter and POD enzyme activity using the data from 2017. statistical tests were performed using Statistica ${ }^{\circledR}$ v. 12 (StatSoft Inc., Tulsa, OK, USA).

\section{Results}

\section{Enzymatic antioxidants} sented in Tab. S1 (Supplementary material). tendency was not observed in the other provenances. No significant change was discovered in the POD and PPO activities by comparing different years of sampling, and there were only a few notable changes of activity among provenances within each year.

As the simple ANOVA evaluation of primary data did not show any apparent and unequivocal results, linear correlation analysis was applied to find possible relationships between chemical parameters as well as growth characteristics and ecodistance. Linear correlation analysis results are summarized in Tab. 2. According to these, there was a significant positive correlation $(p<0.15)$ between average stem diameter and POD enzyme activity in 2016 and 2017, while in 2015 the relationship displayed the same tendency; however, this tendency proved insignificant.

Fig. 2 depicts the correlation equation of 2017, which clearly shows that the Atlantic provenances with poorer growth and survival rates (Gråsten, Torup) display the lowest POD enzyme activity. Interestingly, Pidkamin is located closest to the weak performing provenances in Fig. 2 and was characterized by low POD activity and stem diameter. Vigorous height growth was observed in this provenance (not shown), contrary to low diameter, which is not re-

ances using Bartlett's Chi-square test. All

Data of this primary evaluation of POD, PPO, and leaf protein content are preA significant $(p<0.05)$ increase of the total protein content was found in some of the provenances from 2015 to 2017 (Farchau, Pidkamin, Magyaregregy); however, this

\section{flected in Fig. 2.}

PPO enzyme has shown a negative correlation with ecodistance, yet the relationship was significant only in 2016. Ecodistance was also correlated negatively with POD, but significance was only evidenced for the 2015 data.

There was a notable positive correlation between total protein content and ecodistance in all three investigation years. Provenances that had originally adapted to a warmer and drier climate (e.g., Pidkamin) had lower total protein levels and showed better growth performance compared to the provenances with higher ecodistance (e.g., Gråsten).

Fig. 3 displays the correlation for 2017. Fig. 3 also demonstrates the shifting of the climate index of Bánokszentgyörgy, next to Bucsuta, which is regarded as a local control population. This population should have been theoretically positioned at the $\Delta \mathrm{EQ}=0$ position in Fig. 3 , but the $\mathrm{EQ}$ value of the local climate has already shifted due to the warmer and drier weather of the past 15 years. The Hungarian provenance Magyaregregy appears as an outlier. Investigations have proven that this provenance is of unknown origin, and that it was planted as part of afforestation in an area of decayed forests. Furthermore, it has grown under the influence of local climate.

\section{The non-enzymatic antioxidant system}

\section{Primary results}

The results on the ABTS antioxidant capacity as well as average stem diameter from 2014 and Ellenberg's climate quotient are summarized in Tab. 3. 
According to Tab. 3, the provenances with the poorest growth parameters (Gråsten, Torup) had the highest ABTS levels in their leaves, yet differences were not always significant. Many types of compounds contribute to ABTS antioxidant capacity. Fig. S1 in Supplementary material shows an example of a PDA chromatogram of beech leaf extract.

The amounts of individual compounds were assessed by their respective MRM peak areas instead of determining absolute concentrations as detailed above. The MRM peak areas corresponding to one given compound in the eight individual trees of a given provenance were averaged. The averaged peak areas for each compound and provenance are included in Tab. S2 (Supplementary material). According to Tab. 3 and Tab. S2, apparent differences existed not only in ABTS antioxidant capacity, but also in polyphenolic composition. In the poorest growing provenances (previously characterized with the highest ABTS values), the levels of some polyphenols were also the highest (e.g., Caffeic acid-O-hexoside, Unknown 2; Quercetin-Ohexoside 1 and 2; Quercetin-O-pentoside; Kaempferol-O-pentoside) or, surprisingly, the lowest (Unknown 1, 3 and 6; Procyanidin B dimer 5 and 6; Procyanidin $C$ trimer 6).

\section{Correlation analysis of primary data}

From the Tab. 3 data it was assumed that translocation induced more intense stress in the individuals of these provenances. It was also assumed that the elevated ABTS

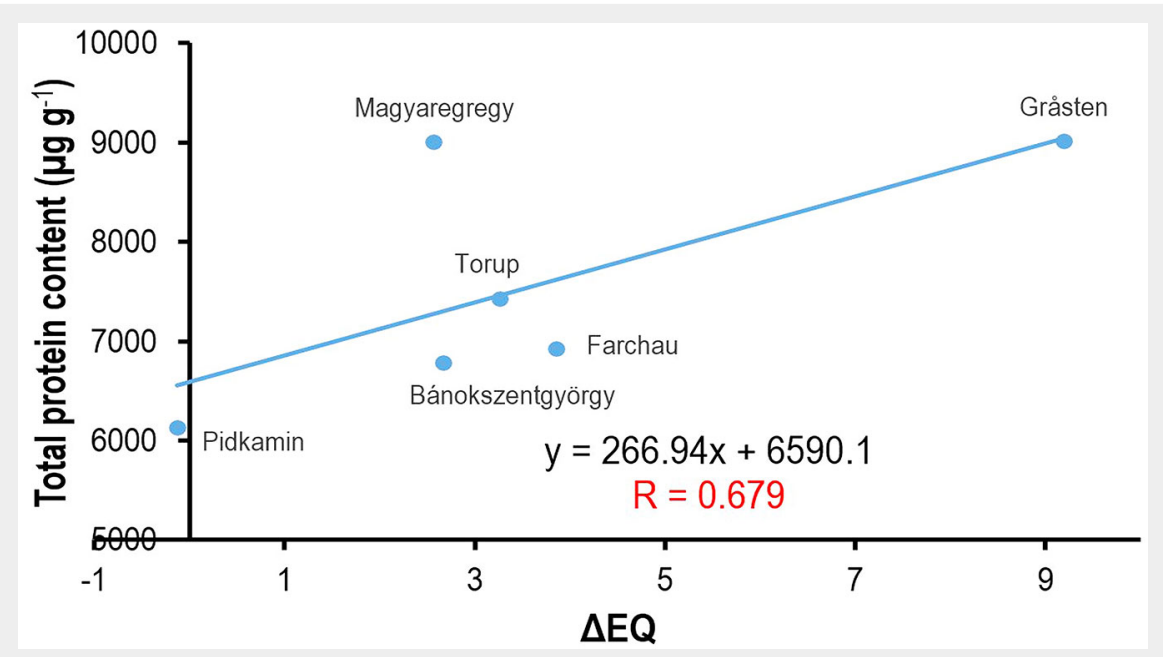

Fig. 3 - Correlation between ecodistance $(\triangle \mathrm{EQ})$ and total protein content using the data from 2017.

Tab. 3 - Average stem diameters, ABTS antioxidant capacity, and Ellenberg's climate quotient (EQ) of the investigated provenances for the samples from 2014. Results are given as mean \pm std. deviation when applicable. Significant differences at $p<0.01$ level $(n=8)$ are denoted with different upper case letters in a given column.

\begin{tabular}{lccc}
\hline Provenance & $\begin{array}{c}\text { ABTS } \\
\left(\mathbf{m g ~ t r o l o x ~} \mathbf{~ g}^{-1} \mathrm{dw}\right)\end{array}$ & $\begin{array}{c}\text { Average stem } \\
\text { diameter }(\mathbf{c m})\end{array}$ & EQ \\
\hline Farchau (26) & $120.7 \pm 49.7^{\mathrm{a}}$ & $6.4 \pm 2.5^{\mathrm{a}}$ & 25.59 \\
\hline Pidkamin (59) & $155.8 \pm 27.9^{\mathrm{a}}$ & $7.4 \pm 1.7^{\mathrm{ab}}$ & 29.58 \\
\hline Torup(23) & $202.1 \pm 33.2^{\mathrm{ab}}$ & $5.1 \pm 2.2^{\mathrm{a}}$ & 26.18 \\
\hline B.szentgyörgy (H1) & $163.5 \pm 78.7^{\mathrm{a}}$ & $8.6 \pm 2.8^{\mathrm{ab}}$ & 26.77 \\
\hline M.egregy(52) & $178.2 \pm 54.9^{\mathrm{a}}$ & $11.4 \pm 4.6^{\mathrm{b}}$ & 26.87 \\
\hline Gråsten (21) & $296.2 \pm 84.4^{\mathrm{b}}$ & $5.6 \pm 1.7^{\mathrm{a}}$ & 20.26 \\
\hline
\end{tabular}

Tab. 4 - Correlation of polyphenol levels with ABTS levels, Ellenberg's climate quotients (EQ), as well as with average stem diameter (ASD). Statistically significant $(p<0.05, n=6 ;|R| \geq 0.812)$ correlation coefficients are marked with an asterisk.

\begin{tabular}{|c|c|c|c|c|c|c|c|}
\hline Compound & ABTS & EQ & ASD & Compound & ABTS & EQ & ASD \\
\hline Quercetin- $O$-hexoside 1 & $0.937^{*}$ & -0.756 & -0.202 & Coniferin isomer & -0.359 & -0.265 & -0.197 \\
\hline Coniferin derivative 2 & $0.919^{*}$ & -0.706 & -0.001 & Coniferin derivative 3 & -0.392 & 0.791 & 0.311 \\
\hline$(-)$-Epicatechin & $0.903^{*}$ & -0.781 & -0.429 & Procyanidin B dimer 5 & -0.558 & 0.493 & 0.808 \\
\hline Quercetin-O-hexoside 2 & $0.889^{*}$ & -0.678 & -0.107 & Procyanidin $\mathrm{C}$ trimer 8 & -0.561 & $0.872^{*}$ & 0.216 \\
\hline Quercetin-O-pentoside & $0.876^{*}$ & -0.693 & -0.256 & Unknown 1 & -0.572 & 0.677 & 0.790 \\
\hline$(+)$-Catechin & $0.873^{*}$ & $-0.834^{*}$ & -0.084 & Unknown 3 & -0.594 & 0.707 & 0.677 \\
\hline Caffeic acid-0-hexoside & $0.872^{*}$ & -0.632 & -0.393 & Procyanidin B dimer 6 & -0.639 & 0.097 & 0.137 \\
\hline Procyanidin C trimer 3 & $0.870^{*}$ & $-0.851^{*}$ & -0.222 & Procyanidin C trimer 7 & -0.665 & 0.784 & 0.057 \\
\hline Procyanidin B dimer 4 & $0.825^{*}$ & $-0.838^{*}$ & -0.143 & Feruloylthreonic acid & -0.683 & 0.314 & 0.679 \\
\hline Procyanidin $\mathrm{C}$ trimer 4 & $0.817^{*}$ & -0.757 & -0.312 & Procyanidin $\mathrm{C}$ trimer 5 & -0.694 & 0.304 & 0.379 \\
\hline Kaempferol-O-hexoside 2 & $0.815^{*}$ & -0.627 & -0.059 & Naringenin- $C$-hexoside 2 & -0.733 & 0.539 & 0.344 \\
\hline Quercetin-O-glucuronide & 0.811 & -0.555 & -0.445 & Unknown 4 & -0.759 & 0.656 & 0.582 \\
\hline Procyanidin B dimer 2 & 0.761 & -0.513 & -0.330 & Unknown 5 & -0.785 & 0.793 & 0.642 \\
\hline Kaempferol-O-hexoside 1 & 0.740 & -0.505 & -0.014 & Naringenin- $C$-hexoside 1 & -0.807 & 0.638 & 0.304 \\
\hline Kaempferol-O-pentoside & 0.732 & -0.531 & -0.156 & Naringenin- $C$-hexoside 3 & $-0.824^{*}$ & 0.672 & 0.237 \\
\hline Unknown 2 & 0.650 & -0.435 & -0.078 & Procyanidin C trimer 2 & $-0.829^{*}$ & $0.869^{*}$ & 0.075 \\
\hline Procyanidin $\mathrm{C}$ trimer 1 & 0.605 & -0.525 & 0.192 & Procyanidin B dimer 1 & $-0.849^{*}$ & 0.441 & 0.033 \\
\hline Coniferin derivative 1 & 0.534 & 0.007 & -0.098 & Procyanidin B dimer 8 & $-0.849^{*}$ & 0.778 & 0.013 \\
\hline Chlorogenic acid isomer 2 & 0.519 & -0.200 & -0.174 & Unknown 6 & $-0.900^{*}$ & $0.848^{*}$ & 0.658 \\
\hline Chlorogenic acid isomer 1 & 0.382 & 0.163 & 0.514 & Procyanidin B dimer 3 & $-0.908^{*}$ & 0.574 & 0.498 \\
\hline Chlorogenic acid isomer 3 & 0.251 & 0.135 & 0.765 & Procyanidin C trimer 6 & $-0.944^{*}$ & 0.688 & 0.497 \\
\hline Kaempferol-O-deoxyhexoside & -0.343 & 0.660 & 0.469 & Procyanidin B dimer 7 & $-0.954^{*}$ & 0.782 & 0.172 \\
\hline
\end{tabular}


antioxidant capacities may be a response to this stress.

We surmised that a significant positive correlation between ABTS antioxidant capacity levels and the concentration of a given compound indicates a strong influence on the antioxidant properties of the leaf extracts; hence, it is an "efficient" antioxidant compound, which is likely to contribute significantly to the stress response of the plant (Hofmann et al. 2017b).

Tab. 4 summarizes the correlation analysis results. According to these, QuercetinO-hexoside $1(\mathrm{R}=0.937)$, Quercetin-O-hexoside $2(R=0.889)$, Coniferin derivative $2(R=$ 0.919), (+)-Catechin ( $R=0.873),(-)$-Epicatechin ( $R=0.903)$, Quercetin-O-pentoside ( $R=$ $0.876)$, Caffeic acid-O-hexoside ( $R=0.872)$, Kämpferol-O-hexoside $2(\mathrm{R}=0.815)$, Procyanidin $B$ dimer $3(R=0.825)$, Procyanidin $C$ trimer $3(R=0.870)$ and Procyanidin $C$ trimer $4(R=0.817)$ were the most efficient antioxidants. Interestingly, some compounds also indicated noteworthy negative correlations $(R<-0.812)$. A possible explanation is that these compounds may have pro-oxidant effects in beech leaf extracts assessed by the ABTS method. The antioxidant behavior of isomers (especially those of Procyanidin B and C isomers) seems to be markedly different. Generally, the antioxidant and radical scavenging abilities of condensed procyanidins increases with the growing degree of polymerization (DP Pedan et al. 2016, Zhang et al. 2017), yet evidence for significant differences between the antioxidant efficiency of procyanidin isomers with similar DP also exists (Hofmann et al. 2017b).

Obviously, many types of compounds contribute to the antioxidant capacity of leaf extracts. This raises the question of whether there are any special indicator compounds that influence ABTS antioxidant capacity significantly and also act as indicators of translocation stress response. To examine these effects, a linear correlation analysis between polyphenol concentration and EQ and average stem diameter was completed (Tab. 4).

The correlations have shown that the provenances with higher EQ (originating from warmer and more arid regions of Europe) had lower levels of some of the most efficient antioxidant compounds, indicated by a significant negative correlation $((+)-$ Catechin, Procyanidin C trimer 3 and Procyanidin B dimer 4 ). It may be concluded that the provenances originally adapted to a drier and warmer climate do not tend to produce efficient antioxidant polyphenols in excess, as they are better acclimated to the warmer/drier test conditions in Bucsuta. These provenances have also shown better diameter growth compared to low EQ provenances with weaker acclimation potential. Weaker acclimation potential of provenances to local conditions was not only evidenced by smaller diameters, but also by a higher tree mortality rate (data not shown).
Findings are also in accordance with earlier results on growth responses (Horváth \& Mátyás 2016). Average stem diameter, as a direct measure of provenance growth and performance, showed no significant correlation with either of the identified compounds. Interestingly, some compounds (Procyanidin C trimer 2 and 8, Unknown 6) have shown elevated levels (significant positive correlations with the EQ value) in these provenances. This finding requires further explanation.

\section{Discussion}

In general, increased antioxidant concentrations are associated with increased stress, caused mostly by elevated ozone levels, UV radiation, drought, and extreme temperature conditions in forest trees (Luwe 1996, Haberer et al. 2008).

The POD and PPO enzymes in plants have several known functions (e.g., in lignin biosynthesis, ethylene production, indole-3acetic acid metabolism, enzymatic browning, heartwood formation, etc.). The increase of their activity is considered a nonspecific and general response to oxidative stress in living cells (Laukkanen et al. 1999, Tang \& Newton 2004, Gupta et al. 2018).

For Pinus (Zheng et al. 2012) and Picea (Bae et al. 2010, Pukacki \& Kaminska-Rozek 2013) spp. the increased amount of antioxidant enzymes in the needles was already reported during the acclimation process.

According to present results, the provenances of poorer growth performance were characterized by the lower POD enzyme activities of the leaves. The tendency was the same with PPO enzyme, yet correlation relationships were not significant. Normally, oxidative stress triggers an increase of POD levels in tree leaves (Boughalleb \& Mhamdi 2011, Chakhchar et al. 2015a, 2015b, Song et al. 2015) while the changes of PPO activity are variable, depending on species, stress tolerance, and circumstances (Vahdati \& Lotfi 2013, Song et al. 2015, Li et al. 2020). According to the correlation between POD vs. stem diameter, a decrease of activity in the provenances with lower stem diameters was experienced, which together with the generally lower tree vigor and higher tree mortality rate indicates that their long-term acclimation has not been successful, leading to decreased enzyme activities in the exhaustion phase of the stress response ( $\mathrm{Se}$ lye 1950). The positive correlation of POD with growth (Tab. 2.) shows that the general increase experienced in the leaves of other tree species during stress also applies here.

The variation of the correlations between PPO vs. diameter of the three investigated years also supports the previous statements on the PPO enzyme activity variability, depending on different factors.

The general negative correlations between enzyme activities and ecodistance also support the finding that provenances originally adapted to warmer and drier cli- mates tend to have higher enzyme activities, yet this may be influenced by many factors, which is reflected by the weak correlation coefficients.

According to Baniulis et al. (2020) the comparative analysis of the protein content in the needles of pine seedlings provide insights into adaptation processes at the cellular level and the adaptive capacity within plant species.

According to Zhang et al. (2012), the total (Bradford) protein content in the leaves of Populus cathayana cuttings increased under drought stress. Conversely, Kala \& Godara (2011) found decreased total protein content in the leaves of Ziziphus mauritania L. under moisture stress (water deprivation), which was attributed to increased protease activity or decreased protein synthesis or a combination of both of these factors.

According to Korotaeva et al. (2015) the accumulation of dehydrins localized mostly in chloroplast and in the mitochondria membrane system was observed in pine needles during acclimation experiments. Generally, the types of proteins in leaves vary greatly; therefore, the changes in the total amount of proteins is extremely complex and can be influenced by many factors. In our findings, the provenances originally adapted to a cooler and wetter climate (e.g., Gråsten) also had higher levels of total proteins and also exhibited poorer growth under higher drought stress. In this respect, the total protein content of leaves may not only be a marker of drought, but of other environmental stress responses in tree leaves as well.

Under stress, plant polyphenol composition can change due to increased phenylpropanoid metabolism (Dixon \& Paiva 1995, Isah 2019). Polyphenols may account for the major portion of the antioxidant activity of tree leaves, as Lee et al. (2009) demonstrated with olive leaves.

However, the levels of different polyphenolic compounds can also behave differently under stress conditions, for example in water-stressed poplar plants, the water deficit increased some polyphenol levels, including flavonoids (chrysin, myricetine, kaempferol) and isoferulic acid in roots as well as total phenols and antioxidant capacity in the leaves (Popovic et al. 2016). One explanation for the differing behavior of polyphenolic compounds is their varied role in defense and signaling processes in plants. Moreover, under certain circumstances, polyphenols can act as pro-oxidant compounds (Smirnoff 2005, Hofmann et al. 2017b), demonstrating that their concentration may decrease in the living tissue during defense reactions. The different behaviors of beech leaf polyphenols was also indicated by the significant correlations between ABTS antioxidant capacity and by the EQ vs. polyphenol concentration, as evidenced both by positive and negative values (Tab. 4). According to many recent reports detailed in Isah (2019), the produc- 
tion of secondary metabolites, including polyphenols, increase in drought as well as in cold stress; however, in most cases this is accompanied by a decrease of biomass production. This is in accordance with the findings as the highest ABTS antioxidant capacities were found for the provenances with the poorest growth parameters (average stem diameter).

The role of individual polyphenolic compounds depends on the antioxidant efficiency of these compounds and on the potential of participating in plant defense reactions. According to Tab. 4 , the most efficient compounds contributing to ABTS antioxidant power (showing the best positive correlations with the ABTS levels) in beech leaves were Quercetin-O-hexosides, Quercetin-O-pentoside, Coniferin derivative 2, (+)-Catechin and (-)-Epicatechin. According to Tab. S2 (Supplementary material), these compounds have generally higher concentrations in the provenances with poorer growth, which also confirms the role of these compounds in stress response processes in beech. According to Di Ferdinando et al. (2012) only a few glycosylated flavonoids are effective antioxidants compared to their respective aglycone part; however, the present study found the glycoside conjugates of quercetin to be the most efficient polyphenolic antioxidants. The flavan-3-ols (+)-Catechin and (-)-Epicatechin have been known to be efficient antioxidants in other plant tissues (Hofmann et al. 2017b) and contribute significantly to the defense reaction in beech leaf tissues (Feucht et al. 1994, 1997) and the defense reaction in other plant tissues (Feucht et al. 1996, Feucht \& Treutter 1999, Hofmann et al. 2008). Some compounds had pro-oxidant effects. The roles of these compounds need to be clarified in the future.

The complex roles that different types of secondary metabolites play in the antioxidant system of beech was shown by Stajner et al. (2013), who pointed out that the adaptability of different beech provenances to environmental factors was best in the case of high FRAP value and free proline and soluble proteins contents, which proves the combined effects of different types of metabolites.

The results of the current study are in accordance with the results of Berini et al. (2018), outlining that the presence and concentration of secondary metabolites may be adaptive. Results demonstrated the concentration change of antioxidants related to the sensed climatic change in beech provenances. The correlations between metabolite concentrations and growth rate indicate that the application of antioxidants as stress indicators is only partly possible due to the complex effects of various abiotic factor combinations (Berini et al. 2018). Regarding the genetic background of the relatively high acclimatization potential of beech, the distinction between a priori coded genetic responses, acclimation and/or epigenetic effects is a secondary issue, as the latter must be linked to genetics as well (Münzbergová et al. 2018).

\section{Conclusions}

The present study investigated general relationships between acclimation and leaf antioxidant properties in beech by provenance trials. Our study is among the first to show that genetic differences in observed acclimation processes between populations do affect antioxidant types and concentrations. We have concluded that the response to translocation-simulated climatic stress depends on the original genetic adaptation of the provenances, and that differences may be tracked using the illustrated biochemical analyses. Statistical analyses of variance did not always indicate significant differences between provenances because of highly unexplained variation; but correlation analyses revealed significant trends between biochemical parameters and growth as well as for simulated climate stress. Certain polyphenol concentrations, POD enzyme activity, and total protein content may serve as chemical indicators of the acclimation potential of populations and may contribute to the forecasting of climate change effects. In the course of planning adaptive forest management, differences in acclimation potential have to be considered when deciding about priorities for tree species and provenances. Knowledge of phytochemical processes and indicators of acclimation may support such decisions. Future research studies should focus on the roles of other compounds in enzymatic and non-enzymatic antioxidant systems and on the structural elucidation of the compounds labelled as "unknown".

\section{Acknowledgements}

This research was supported by the János Bolyai Research Scholarship of the Hungarian Academy of Sciences and was financed by the EU-Hungary joint research project VKSZ 12-1-2013-0034 Agrárklíma.2.

Results on chromatographic separation and relative quantitative evaluation of polyphenols were republished with kind permission of International Labmate Ltd. (St. Albans, UK) The evaluation was first published in International Labmate Volume 42, Issue 3 (April 2017).

\section{References}

Achmadi SS (2019). Polyphenols resources in Indonesia from economic perspective. In: "Polyphenols in Plants ( $2^{\text {nd }}$ edn). Isolation, Purification and Extract Preparation" (Watson RR ed). Academic press, San Diego, CA, USA, pp. 67-79. doi: 10.1016/B978-0-12-813768-0.00005-0

Allen CD, Breshears DD, MCDowell NG (2015). On underestimation of global vulnerability to tree mortality and forest die-off from hotter drought in the Anthropocene. Ecosphere 6: 155. - doi: 10.1890/ES15-00203.1

Aranda I, Sánchez-Gómez D, De Miguel M, Mancha JA, Guevara MA, Cadahía E, Fernández De
Simón MB (2017). Fagus sylvatica L. provenances maintain different leaf metabolic profiles and functional response. Acta Oecologica 82: 1-9. - doi: 10.1016/j.actao.2017.05.003 Bae JJ, Choo YS, Ono K, Sumida A, Hara T (2010). Photoprotective mechanisms in cold-acclimated and nonacclimated needles of Picea glehnii. Photosynthetica 48: 110-116. - doi: 10.1017/s1109 9-010-0015-6

Baniulis D, Sirgediene M, Haimi P, Tamošiune I, Danusevičius D (2020). Constitutive and cold acclimation-regulated protein expression profiles of scots pine seedlings reveal potential for adaptive capacity of geographically distant populations. Forests 11: 89. - doi: 10.3390/f11010 089

Berini JL, Brockman SA, Hegeman AD, Reich PB, Muthukrishnan R, Montgomery RA, Forester JD (2018). Combinations of abiotic factors differentially alter production of plant secondary metabolites in five woody plant species in the boreal-temperate transition zone. Frontiers in Plant Science 9: 1257. - doi: 10.3389/fpls.2018.01 257

Berki I, Rasztovits E, Móricz N, Mátyás C (2009). Determination of the drought tolerance limit of beech forests and forecasting their future distribution in Hungary. Cereal Research Communications 37: 613-616. - doi: 10.1556/CRC.37.20 09.Suppl.4

Boughalleb F, Mhamdi M (2011). Possible involvement of proline and the antioxidant defense systems in the drought tolerance of three olive cultivars grown under increasing water deficit regimes. Agricultural Journal 6: 378-391. - doi: 10.3923/aj.2011.378.391

Bradford MM (1976). A rapid sensitive method for the quantitation of microgram quantities of protein utilising the principle of protein-dye binding. Analytical Biochemistry 72: 248-254. doi: 10.1006/abio.1976.9999

Cadahía E, Fernández De Simón B, Aranda I, Sanz M, Sánchez-Gómez D, Pint E (2015). Non-targeted metabolomic profile of Fagus sylvatica L. leaves using liquid chromatography with mass spectrometry and gas chromatography with mass spectrometry. Phytochemical Analysis 26: 171-182. - doi: 10.1002/pca.2549

Caudullo G, Welk E, San-Miguel-Ayanz J (2017). Chorological maps for the main European woody species. Data in Brief 12: 662-666. - doi: 10.1016/j.dib.2017.05.007

Chakhchar A, Lamaoui M, Wahbi S, Ferradous A, El Mousadik A, Ibnsouda-Koraichi S, Filali-Maltouf A, El Modafar C (2015a). Differential drought tolerance of four contrasting Argania spinosa ecotypes assessed by enzymatic and non-enzymatic antioxidant. International Journal of Recent Scientific Research 6: 3002-3009. Chakhchar A, Wahbi S, Lamaoui M, Ferradous A, El Mousadik A, Ibnsouda-Koraichi S, Filali-Maltouf A, El Modafar C (2015b). Physiological and biochemical traits of drought tolerance in Argania spinosa. Journal of Plant Interactions 10: (1) 252-261. - doi: 10.1080/17429145.2015.1068386

Comps B, Thiébault B, Merzeau D, Letouzey J (1990). Allozymic variability in beechwoods (Fagus sylvatica L.) over Central Europe: spatial differentiation among and within stands. Heredity 65: 407-417. - doi: 10.1038/hdy.1990.111 Comps B, Mátyás Cs Geburek J, Letouzey J 
(1998). Genetic variation in beech populations along the Alps chain and in the Hungarian Basin. Forest Genetics 5: 1-9. [online] URL: http://kf.tuzvo.sk/sites/default/files/FG05-1_001009.pdf

Czúcz B, Gálhidy L, Mátyás C (2011). Present and forecasted xeric climatic limits of beech and sessile oak distribution at low altitudes in Central Europe. Annals of Forest Science 68 (1): 99108. - doi: 10.1007/s13595-011-0011-4

Dalmagro AP, Camargo A, Filho HHS, Valcanaia MM, De Jesus PC, Zeni ALB (2018). Seasonal variation in the antioxidant phytocompounds production from the Morus nigra leaves. Industrial Crops and Products 123: 323-330. - doi: 10.1016/j.indcrop.2018.06.085

Del Río LA (2015). ROS and RNS in plant physiology: an overview. Journal of Experimental Botany 66 (10): 2827-37. - doi: 10.1093/jxb/ervo99

Di Ferdinando $M$, Brunetti C, Fini A, Tattini $M$ (2012). Chapter 9 - Flavonoids as antioxidants in plants under abiotic stresses. In: "Abiotic Stress Responses in Plants" (Ahmad P, Prasad MNV eds). Springer, New York, USA, pp. 159179. - doi: 10.1007/978-1-4614-0634-1 9

Dixon RA, Paiva NL (1995). Stress-induced phenylpropanoid metabolism. The Plant Cell 7: 10851097. - doi: 10.1105/tpc.7.7.1085

Ellenberg H (1988). Vegetation ecology of Central Europe ( $4^{\text {th }}$ edn). Cambridge University Press, Cambridge, UK, pp. 731. - doi: 10.1002/ fedr.19901010711

Feucht W, Treutter D (1999). The role of flavan-3ols and proanthocyanidins in plant defense. In: "Principles and Practices of Plant Ecology" (Inderjit, Dakshini KMM, Foy CL eds). CRC Press LLC, Boca Raton, FL, USA, pp. 308-332.

Feucht W, Treutter D, Christ E (1994). Accumulation of flavanols in yellowing beech leaves from forest decline sites. Tree Physiology 14: 403-412. - doi: 10.1093/treephys/14.4.403

Feucht W, Treutter D, Christ E (1996). Flavanols in grapevine: in vitro accumulation and defence reactions in shoots. Vitis 35: 113-118.

Feucht W, Treutter D, Christ E (1997). Role of flavanols in yellowing trees of the Black Forest. Tree Physiology 17: 335-340. - doi: 10.1093/tree phys/17.5.335

Flurkey WH, Jen JJ (1978). Peroxidase and polyphenol oxidase activities in developing peaches. Journal of Food Science 43: 1826-1829. - doi: 10.1111/j.1365-2621.1978.tb07424.x

Foyer C, Noctor G (2005). Oxidant and antioxidant signaling in plants: a reevaluation of the concept of oxidative stress in a physiological context. Plant, Cell and Environment 28 (8): 1056-1071. - doi: 10.1111/j.1365-3040.2005.01327.x Grace SC, Logan BA (1996). Acclimation of foliar antioxidant systems to growth irradiance in three broad-leaved evergreen species. Plant Physiology 112: 1631-1640. - doi: 10.1104/pp.112.4. 1631

Gupta DK, Palma JM, Corpas FJ (2018). Antioxidants and antioxidant enzymes in higher plants. Springer International Publishing, eBook, 300. - doi: 10.1007/978-3-319-75088-0 Haberer K, Herbinger K, Alexou M, Rennenberg $H$, Tausz M (2008). Effects of drought and canopy ozone exposure on antioxidants in fine roots of mature European beech (Fagus sylvatica). Tree Physiology 28: 713-719. - doi: 10.1093/ treephys $/ 28.5 .713$

Hijmans RJ, Cameron SE, Parra JL, Jones PG, Jarvis A (2005). Very high resolution interpolated climate surfaces for global land areas. International Journal of Climatology 25: 19651978. - doi: 10.1002/joc.1276

Hofmann T, Albert L, Rétfalvi T, Visi-Rajczi E, Brolly $G$ (2008). TLC analysis of the in vitro reaction of beech (Fagus sylvatica L.) wood enzyme extract with catechins. Journal of Planar Chromatography 21: 83-88. - doi: 10.1556/JPC.21.200 8.2.2

Hofmann T, Nebehaj E, Albert L (2015). The highperformance liquid chromatography/multistage electrospray mass spectrometric investigation and extraction optimization of beech (Fagus sylvatica L.) bark polyphenols. Journal of Chromatography A 1393: 96-105. - doi: 10.1016/j. chroma.2015.03.030

Hofmann T, Tálos-Nebehaj E, Albert L (2017a). Leaf polyphenols as indicators of climatic adaptation of beech (Fagus sylvatica L.) - an HPLCMS/MS via MRM approach. International Labmate 42 (3): 12-14. [online] URL: http://real. mtak.hu/63756/

Hofmann T, Tálos-Nebehaj E, Albert L, Németh L (2017b). Antioxidant efficiency of beech (Fagus sylvatica L.) bark polyphenols assessed by chemometric methods. Industrial Crops and Products 108: 26-35. - doi: 10.1016/j.indcrop.20 17.06.016

Horváth A, Mátyás C (2014). Növedékcsökkenés elörevetítése egy bükk származási kísérlet alapján [Estimation of increment decline caused by climate change, based on data of a beech provenance trial]. Erdészettudományi Közlemények 4: 91-99. [in Hungarian with English summary]

Horváth A, Mátyás C (2016). The decline of vitality caused by increasing drought in a beech provenance trial predicted by juvenile growth. South-east European Forestry 7 (1): 21-28. - doi: 10.15177/seefor.16-06

Isah T (2019). Stress and defense responses in plant secondary metabolites production. Biological Research 52: 39. - doi: 10.1186/s40659019-0246-3

Kala S, Godara AK (2011). Effect of moisture stress on leaf proteins, proline and free amino acid content in commercial cultivars of Ziziphus mauritiana. Journal of Scientific Research 55: 65-69.

Korotaeva N, Romanenko A, Suvorova G, Ivanova MV, Lomovatskaya L, Borovskii G, Voinikov $V$ (2015). Seasonal changes in the content of dehydrins in mesophyll cells of common pine needles. Photosynthesis Research 124: 159-169. doi: 10.1007/s11120-015-0112-2

Lakatos F, Molnár M (2009). Mass mortality of beech (Fagus sylvatica L.) in south-west Hungary. Acta Silvatica et Lignaria Hungarica 5: 7582. [online] URL: http://publicatio.nyme.hu/114/ 1/06_lakatos_molnar_p.pdf

Laukkanen H, Haggman H, Kontunen-Soppela S, Hohtola A (1999). Tissue browning of in vitro cultures of Scots pine: role of peroxidase and polyphenol oxidase. Physiologia Plantarum 106: 337-343. - doi: 10.1034/j.1399-3054.1999.106312.x Lee OH, Lee BY, Lee J, Lee H, Son J, Park C, Shetty K, Kim YC (2009). Assessment of phenolics enriched extract and fractions of olive leaves and their antioxidant activities. Bioresource Technology 100: 6107-6113. - doi: 10.1016 j.biortech.2009.06.059

Li S, Zhou L, Addo-Danso SD, Ding G, Sun M, Wu $S$, Lin S (2020). Nitrogen supply enhances the physiological resistance of Chinese fir plantlets under polyethylene glycol (PEG)-induced drought stress. Scientific Reports 10: 7509. doi: 10.1038/s41598-020-64161-7

Linnakoski R, Kasanen R, Dounavi A, Forbes KM (2019). Editorial: forest health under climate change: effects on tree resilience, and pest and pathogen dynamics. Frontiers in Plant Science 10: 1157. - doi: 10.3389/fpls.2019.01157

Luwe M (1996). Antioxidants in the apoplast and symplast of beech (Fagus sylvatica L.) leaves: seasonal variations and responses to changing ozone concentrations in air. Plant Cell and Environment 19: 321-328. - doi: 10.1111/j.1365-3040.19 96.tboo254.x

Mátyás C (1994). Modelling climate change effects with provenance test data. Tree Physiology 14: 797-804. - doi: 10.1093/treephys/14.7-89.797

Mátyás C, Berki I, Czúcz B, Gálos B, Móricz N, Rasztovits E (2010). Future of beech in Southeast Europe from the perspective of evolutionary ecology. Acta Silvatica et Lignaria Hungarica 6: 91-110. [online] URL: http://publicatio.nym e.hu/110/1/08_matyas_et_al_p.pdf

Münzbergová Z, Latzel V, Surinová M, Hadincová $\mathrm{V}$ (2018). DNA methylation as a possible mechanism affecting ability of natural populations to adapt to changing climate. Oikos 128: 124-134. doi: 10.1111/oik.05591

Pedan V, Fischer N, Rohn S (2016). An online NPHPLC-DPPH method for the determination of the antioxidant activity of condensed polyphenols in cocoa. Food Research International 89 (2): 890-900. - doi: 10.1016/j.foodres.2015.10.030 Pennycooke JC, Cox S, Stushnoff C (2005). Relationship of cold acclimation, total phenolic content and antioxidant capacity with chilling tolerance in petunia (Petunia $\times$ hybrida). Environmental and Experimental Botany 53 (2): 225232. - doi: 10.1016/j.envexpbot.2004.04.002

Penuelas J, Ogaya R, Boada M, Jump AS (2007). Migration, invasion and decline: changes in recruitment and forest structure in a warminglinked shift of European beech forest in Catalonia (NE Spain). Ecography 30: 829-837. - doi: 10.1111/j.2007.0906-7590.05247.x

Popovic BM, Stajner D, Zdero-Pavlovic R, Tumbas-Saponjac V, Canadanovic-Brunet J, Orlovic $S$ (2016). Water stress induces changes in polyphenol profile and antioxidant capacity in poplar plants (Populus spp.). Plant Physiology and Biochemistry 105: 242-250. - doi: 10.1016/j. plaphy.2016.04.036

Pukacki PM, Kaminska-Rozek E (2013). Reactive species, antioxidants and cold tolerance during deacclimation of Picea abies populations. Acta Physiologiae Plantarum 35: 129-138. - doi: 10.1007/s11738-012-1055-2

Sáenz-Romero C, Kremer A, Nagy L, Ujvári-Jármay E, Ducousso A, Kóczán-Horváth A, Hansen JK, Mátyás C (2019). Common garden comparisons confirm inherited differences in sensitivity to climate change between forest tree species. PeerJ 7: e6213. - doi: 10.7717/peerj.6213

Selye H (1950). Stress and the general adapta- 
tion syndrome. British Medical Journal 4667: 1383-1392. - doi: 10.1136/bmj.1.4667.1383

Shannon LM, Kay E, Lew JY (1966). Peroxidase isoenzymes from horseradish roots. Journal of Biological Chemistry 241 (9): 2166-2172. - doi: 10.1016/So021-9258(18)96680-9

Sies H (1991). Oxidative stress: from basic research to clinical application. The American Journal of Medicine 91 (3C): 31-38. - doi: 10.1016/ 0002-9343(91)90281-2

Smirnoff N (2005). Antioxidants and reactive oxygen species in plants. Wiley-Blackwell Pub lishing Ltd, Oxford, UK, pp. 320. - doi: 10.1002/ 9780470988565

Song YY, Simard SW, Caroll A, Mohn WW, Zheng $R$ (2015). Defoliation of interior Douglas fir elic its carbon transfer and defense signaling to ponderosa pine neighbors through ectomycorrhizal networks. Scientific Reports 5 (8495): 1-9. - doi: 10.1038/srepo8495

Stajner D, Orlovic S, Popovic BM, Kebert M, Stojnic S, Klasnja B (2013). Chemical parameters of oxidative stress adaptability in Beech. Journal of Chemistry 2013: 1-8. - doi: 10.1155/2013/5926 95

Stojanovic DB, Kric A, Matovic B, Orlovic S, Duputie A, Djurdjevic V, Galiç Z, Stojnic S (2013). Prediction of the European beech (Fagus sylvatica L.) xeric limit using a regional climate model: an example from southeast Europe. Agricultural and Forest Meteorology 176: 94-103. - doi: 10.1016/j.agrformet.2013.03.009

Stratil P, Klejdus B, Kuban V (2007). Determination of phenolic compounds and their antioxidant activity in fruits and cereals. Talanta 71: 1741-1751. - doi: 10.1016/j.talanta.2006.08.012
Tanase C, Cosarca S, Muntean D-L (2019). A critical review of phenolic compounds extracted from the bark of woody vascular plants and their potential biological activity. Molecules 24 (6): 1182. - doi: $10.3390 /$ molecules 24061182

Tang W, Newton RJ (2004). Increase of polyphenol oxidase and decrease of polyamines correlate with tissue browning in Virginia pine (Pinus virginiana Mill.). Plant Science 167: 621-628. doi: 10.1016/j.plantsci.2004.05.024

Vahdati K, Lotfi N (2013). Abiotic stress tolerance in plants with emphasizing on drought and salinity stresses in walnut. In: "Abiotic Stressplant Responses and Applications in Agriculture" (Vahdati K, Leslie C eds). InTech, Rijeka, Croatia, pp. 307-367. - doi: 10.5772/45842

Visiné Rajczi E, Hofmann T, Albert L, Mátyás C (2018). Az antioxidáns rendszer, mint a bükk (Fagus sylvatica L.) klimatikus alkalmazkodóképességének lehetséges indikátora [Antioxidant system as a potential indicator of the climatic adaptation of beech (Fagus sylvatica L) Erdészettudományi Közlemények 8 (2): 25-35. [in Hungarian with English summary and captions] - doi: 10.17164/EK.2018.019

Von Wuehlisch G, Alia R (2011). COST E52 final report - Genetic resources of European beech (Fagus sylvatica L.) for sustainable forestry. In: Proceedings of the "COST E52 - Evaluation of beech genetic resources for sustainable forestry". Monografías INIA, Serie Forestal 22, pp. 148.

Zhang S, Chen L, Duan B, Korpelainen H, Li C (2012). Populus cathayana males exhibit more efficient protective mechanisms than females under drought stress. Forest Ecology and Man- agement 275: 68-78. - doi: 10.1016/j.foreco.2012. 03.014

Zhang S, Li L, Cui Y, Luo L, Li Y, Zhou P, Sun B (2017). Preparative high-speed counter-current chromatography separation of grape seed proanthocyanidins according to degree of polymerization. Food Chemistry 219: 399-407. - doi: 10.1016/j.foodchem.2016.09.170

Zheng Y, Yang Q, Xu M, Chi Y, Shen R, Li P, Dai H (2012). Responses of Pinus massoniana and Pinus taeda to freezing in temperate forests in central China. Scandinavian Journal of Forest Research 27: 520-531. - doi: 10.1080/02827581.20 12.683532

Zolfaghari R, Hosseini SM, Korori SAA (2010). Relationship between peroxidase and catalase with metabolism and environmental factors in Beech (Fagus orientalis Lipsky) in three different elevations. International Journal of Environmental Sciences 1: 243-252. - doi: 10.6088/ ijes.00102010013

\section{Supplementary Material}

Tab. S1 - POD and PPO enzyme activity, total protein content and average stem diameter at breast height of the investigated provenances.

Tab. S2 - Average $(n=8)$ peak areas for each compound according to provenance.

Fig. S1 - Separation of a beech leaf extract PDA (250-380 nm) chromatogram.

Link: Visi-Rajczi_3542@supplo01.pdf 